Article

\title{
Social Exclusion and Austerity Policies in England: The Role of Sports in a New Area of Social Polarisation and Inequality?
}

\author{
Mike Collins ${ }^{1,+}$ and Reinhard Haudenhuyse ${ }^{2, *}$ \\ ${ }^{1}$ Faculty of Applied Science, University of Gloucestershire, Gloucestershire, GL50 2RH, UK \\ ${ }^{2}$ Sport and Society Research Unit, Department of Sports Policy and Management, Vrije Universiteit Brussel, \\ 1050 Brussels, Belgium; E-Mail: reinhard.haudenhuyse@vub.ac.be \\ + Deceased \\ * Corresponding author
}

Submitted: 24 April 2014 | In Revised Form: 21 January 2015 | Accepted: 10 February 2015 |

Published: 25 June 2015

\begin{abstract}
Poverty still counts as the core of social exclusion from sport and many other domains of people's lives. In the first part of this paper, we shortly describe the recent poverty trends in England, and identify groups that are more at-risk of being poor and socially excluded. We then focus on the relationship between poverty, social exclusion and leisure/sports participation, and describe a case study that addresses young people's social exclusion through the use of sports (i.e., Positive Futures). Although further analysis is warranted, it would seem that growing structural inequalities (including sport participation) - with their concomitant effects on health and quality of life-are further widened and deepened by the policy measures taken by the Conservative-Liberal Democrat coalition in the UK. In addition, within a climate of austerity, sport-based social inclusion schemes are likely to become wholly inadequate in the face of exclusionary forces such schemes envision to combat.
\end{abstract}

\section{Keywords}

austerity; disadvantaged youth; health; social exclusion; social inclusion; sport

\section{Issue}

This article is part of the special issue "Sport for Social Inclusion: Critical Analyses and Future Challenges", edited by Dr. Reinhard Haudenhuyse (Vrije Universiteit Brussel, Belgium) and Professor Marc Theeboom (Vrije Universiteit Brussel, Belgium)

(C) 2015 by the authors; licensee Cogitatio (Lisbon, Portugal). This article is licensed under a Creative Commons Attribution 4.0 International License (CC BY).

\section{Introduction}

In the European Year of Social Inclusion 2010, the EU confirmed the role of sport as "a driver of active social inclusion" (Council of the European Union, 2010), with particular reference to accessibility, disadvantage and gender. In 2003, Collins and Kay (2003) looked at sport and social exclusion in England and came to the conclusion that poverty was the core of social exclusion, often exacerbated by factors of class, gender, age, ethnicity, disability, being at-risk of involvement in crime, and location (i.e., urban or rural). Looking again in
2013, the authors concluded that poverty was increasing after excessive government borrowing, the excesses of the international bankers and the stringent cost cutting measures of the Conservative-Liberal Democrat coalition (Collins \& Kay, 2014). This paper begins by tracing trends in poverty, the prospects of austerity policy measures on poverty and social exclusion, with specific attention to sport participation. We then illustrate efforts to combat social exclusion through the lens of a case study (i.e., Positive Futures). The policy focus of the paper is on England, but may also be of relevance to Scotland and Wales (and even to other 
European regions). Budgetary cuts have happened everywhere. However, the Scottish and Welsh governments have managed this differently. Further research should look at such differences and the short to long term effects on local trends in poverty and sport participation for the whole of Britain.

In terms of social inclusion and sport, two dimensions can be distinguished. The first dimension is "inclusion in sports", which refers to, for example, trends or policy measures in terms of participation in sport regarding groups that are less likely to participate. The second dimension is "inclusion through sport", which refers to, for example, programs or policy measures that are aimed at using sports to "include" deprived, poor or disadvantaged people. Inclusion may then refers to improving people's position on multiple domains, for example, education, employability, housing, health, leisure. Development-through-sport is a concept that is closely related to such a conceptualisation.

The first part of the paper will briefly look at the dimension inclusion in sport and how this is related to trends in poverty and the austerity political climate in England. The analysis we make, needs to be seen as an exploratory discussion on the possible impact of austerity measures, and may also have relevance for regions beyond England. From the discussion it will however become clear that further long-term and in-depth research is required which focuses on the impact of austerity measures under the current government regime on sport participation, poverty and social exclusion. For example, questions need to be addressed if austerity measures (not only in England, but across Europe) accelerate existing trends in poverty and social exclusion, and how such measures are related to sport participation trends, with specific attention to leisure participation of people living in poverty? And more importantly: did the taken austerity measures accelerate such trends? And if they did, how? On the other hand, in the second part, which discusses the case study Positive Futures, we focus on inclusion through sport. Based on existing research, we will critically look how such a sport-based intervention can contribute in improving young people's position. Here too the question needs to be addressed-but is beyond the scope of this paper-if and how austerity measures have an impact on the potential of sport-based interventions which target specific disadvantaged groups in society (incl. the goals such programs have and the living conditions of the targeted groups)? Such questions remain however marginal in existing (sport) policy research.

\section{Trends in Poverty}

Poverty limits peoples' life choices and excludes them from many leisure possibilities and money is listed as the most significant constraint. Money to pay for the costs of playing sports, childcare, transport and so forth (Collins \& Kay, 2014). Many scholars indicate that inequality, poverty and social exclusion are closely linked with each other (e.g., Dierckx \& Ghys, 2013; Giddens, 2001, p. 768; Van Haarlem \& Raeymaeckers, 2013; Vermeulen et al., 2012). Poverty arises when a person has a deficit of economic means compared to the general life standards, resulting in this person becoming socially excluded on various life domains such as education, work and health (Dierckx \& Ghys, 2013; Van Haarlem \& Raeymaeckers, 2013). Poverty is often the root cause of further social exclusion and, in turn, the reproduction of poverty (Ghys, 2014). In other words, the core of social exclusion lies in poverty. Prior to the 1970s in England, as in many countries, the poor were found overwhelmingly in three groups that overlapped: the elderly who had made no private pension provision and were dependent on state pensions; the chronically sick; and the long- term unemployed. But now the poor consist of a much more mixed, dynamic and super-diverse group (Crul, Schneider, \& Lelie, 2013; Jenkins, 2015; Vertovec, 2007). The Office of National Statistics (ONS, 2013) summarized the state of poverty for the whole of the UK as shown in Table 1.

This demonstrates that old-age pensioners have been relatively protected but after the recession child poverty is rising again, and likely to grow more. The large growth has been in the working poor because of increased part-time working, especially amongst women and of low-paid jobs in service trades. Economist Guy Standing (2011) referred to such groups in precarious employment as "the precariat".

Table 1. Poor children, adults, and pensioners, 1994-1995 to 2011-2012 (\% and "relative income", number below 0.6 median after housing costs, in real terms).

\begin{tabular}{lllllll}
\hline & \multicolumn{2}{l}{ Working age adults } & \multicolumn{2}{l}{ Children } & \multicolumn{3}{l}{ Pensioners } \\
& $\%$ & No (millions) & $\%$ & No (millions & $\%$ & No (millions \\
\hline $1994-1995$ & 23 & 7.5 & 37 & 4.7 & 36 & 3.6 \\
$1997-1998$ & 20 & 6.7 & 34 & 4.4 & 31 & 2.9 \\
$2003-2004$ & 14 & 5.0 & 20 & 2.5 & 10 & 1.1 \\
$2007-2008$ & 14 & 5.2 & 19 & 2.5 & 9 & 1.0 \\
$2011-2012$ & 21 & 7.9 & 17 & 3.5 & 14 & 1.6 \\
\hline Change 1998-1999 to & +2 & 1.3 & -7 & -0.9 & -1 & -0.1 \\
$2011-2012$ & & & & & &
\end{tabular}

Source: ONS (2013). 
Additionally the Office showed that:

- $28 \%$ of children live in poor households, half in workless ones;

- $43 \%$ of single parents are "poor";

- The highest levels of poor families can be found in London (because of the highest and rising housing costs), with a marked north-south divide (see also Dorling et al., 2007);

- Ethnic minorities are likely to be strongly represented in the poorest fifth (29\% black, 35\% Asian but $49-51 \%$ of Pakistanis/Bangladeshis often from rural, unskilled backgrounds); and

- A quarter of disabled people in the poorest fifth.

Gender, disability and ethnicity seem to have an additional, summative effect on social exclusion. In this respect, we could use the term "deep exclusion", which Levitas et al. (2007, p. 117) defined as "exclusion across more than one domain or dimension of disadvantage, resulting in severe negative consequences for quality of life, well-being and future life chances". A group that remains largely invisible in sport policy documents, sport research publication and participation surveys are asylum seekers and people without legal staying permits (Collins, 2013). Their invisibility is in stark contrast with their precarious societal positions (see Amara et al., n.d.) for one of the few sport related reports on sport, social inclusion and refugees)

\section{The legacy of the Coalition: The Great Deluge?}

In this section we will briefly sketch the prospects, under the Conservative-Liberal Democrat government's austerity policy measures, of specific groups in society that are at greater risk of being poor and socially excluded. The focus will be on (work-poor) households, young people, women, people with disabilities and people with a nonwestern ethnic background. We take a brief look at the short-term impacts that the Coalition's attempts to reduce public expenditure in the aftermath of the banking crash and world recession have made to different aspects, and specifically in relation to sports. Is David Cameron's Big Society emerging, or perhaps something else is emerging from the abyss of heavy cuts on public expenditure and skewed taxes on work?

The concept "Big Society", refers to a political ideology that, broadly taken, wants people to take a more active role in their communities, transfer more power to local governments and integrate the free-market into all domains of public life. From a more critical viewpoint, one could call it "a-do-it-yourself-society", where consequently the government is expected less to "interfere". A Big Society logically implies a "Small Government" with the overall aim of forcing down public spending. Clarke and Newman (2012) rightfully point out that the economic crisis has not been caused by public spending, but by the greed of bankers and gambling-like cultures of financial centres, which were in the end bailed out by public money.

The formation the Coalition government in 2010 has together with the promotion of the Big Society, resulted in unprecedented spending cuts (Levitas, 2012). Levitas (2012, p. 320) argued that rather than being a necessary response to the economic crisis, the cuts constitute a neo-liberal shock doctrine, that contributes to the progressive destruction of collective provision against risk. Problematically, spending cuts impinge directly on the poor, the sick and the disabled (Levitas, 2012). Using 12 indicators, the National Children's Bureau (2013, p. 1) damningly concluded that the inequality that existed fifty years ago still persists, and has in some respects become worse. Regardless of which index is used (e.g., Gini coefficient), the rise in inequality between 1961 and 2011 has been substantial (Jenkins, 2015). At first sight somewhat surprising, inequality declined during the most recent recession in 2010. But the reason for this is attributed to large income falls for those at the top compared to those at the bottom (Jenkins, 2015). Bluntly put, during and after the recession (and the austerity measures) the rich got a bit less rich (except those at the very top) and the poor stayed mainly poor. Unless a new course of action is taken there is a real risk of sleepwalking into a world where inequality and disadvantage are so deeply entrenched that our children grow up in a state of "social apartheid". In his book Inequality and the 1\%, Dorling (2014) argued that inequality brings with it a culture that divides and makes social mobility almost impossible. He contends that the $1 \%$ on top have a dramatic impact on the lives of the $99 \%$; and this by reducing people's life expectancy, educational and work prospects, as well as their mental health. Dorling further shows that inequality and poverty in the UK is increasing. He writes: "Since the great recession hit in 2008, the $1 \%$ has only grown richer while the rest find life increasingly tough. The gap between the haves and the have-nots has turned into a chasm. While the rich have found new ways of protecting their wealth, everyone else has sugared the penalties of austerity." Jenkins (2015, p. 22) argued that the problem is that the (very) rich may increasingly opt out of, or be less willing to contribute to the collective pot that finances benefits and services, but instead deploy their resources to secure outcomes that are favourable to their own interests via politics, media, or the law. In his study on distribution of income between 1961 and 2011 in the UK, Jenkins (2015) draws attention to the stagnation in real income growth for those at the bottom while at the same time incomes at the top are growing. He continues by stating that there is a growing literature arguing that income inequality growth is harmful because it weakens the fabric of our society and social cohesion in its broadest sense. The fabric refers to a shared experi- 
ence of a common education system, health service, and pensions, etc. (Jenkins, 2015).

Cuts to the incomes of families with children, whether in paid work or not, have according to Levitas (2012) been draconic under the austerity policy of the Coalition government. In relation to precarious employment and work-poor households, the Office of National Statistics (UK) suggested there were 250,000 people on zero-hour contracts (i.e., with no guaranteed work), but a Chartered Institute of Personnel Development survey suggested over a million, with half of employers in hotels, leisure and catering having at least one person on such terms. Having no job or a low-paid and insecure job reduces and puts strains on the income of families and their children. According to Padley and Hirsch (2013, p. 5), 2009-2013 has seen the most sustained reduction in income since 1945, with abolition of the weekly Educational Maintenance Allowance of $£ 10-30$ per pupil weekly. Capping total annual welfare payments at $£ 26,000$ per family was in 2011 , according to senior political correspondent of The Guardian Andrew Sparrow, likely to add 40,000 families to the homeless lists awaiting housing. Cooper and Dumpleton (2013) estimated that over 500.000 families had become dependent on aid from food banks, mostly offered by churches.

Regarding young people, the Prince's Trust (2014) found that amongst those Not in Education, Employment or Training (the so-called NEETS)-estimated to be around a total of 430,000 in the UK-a fifth reckoned they had nothing to live for, two in five said unemployment had led to panic attacks, self-loathing and thoughts of suicide, a fifth of the young women had self-harmed, one in five had turned to drugs or alcohol for solace, while more than half had no parental role model. Poverty carries a female face, since $3 / 4$ of the poorest billion people of the world are women, and, as such, women have a greater vulnerability to poverty. The Women's Resource Centre (2013, p. 33) reported "the government's policies have had a negative impact on women through the loss of jobs, income and services. For example, as most public sector employment is predominantly female, public sector cuts can be expected to affect women disproportionately (Clarke \& Newman, 2012). Furthermore, the caring for elderly family members, children or the sick is largely done by women, who are as such more reliant on public services (Clarke \& Newman, 2012). Additional measures announced will intensify these losses for all but the richest women. This will, amongst others, reduce women's opportunities for sport participation. Collins and Kay (2014) furthermore identified disabled people as a group that is often confronted with deep social exclusion. The authors showed the additive effects of gender and class on disabled people's leisure participation, noting that disabled people are in situations partly determined by social structures, policies and "disabling" attitudes (Collins \& Kay, 2014, p. 140). It is well established that on average disabled people and the households in which they live face greater financial disadvantage in terms of income than their counterparts (McKnight, 2014). Collins and Kay state that disability often implicates extra living, travel and care costs, and consequently, many disabled people and their families depend on welfare benefits, which according to the authors makes them by definition "poor". Even those who are active in the labour market, are disproportionately likely to be employed in work that is poorly paid, low-skilled and part-time (see Haudenhuyse (2015), in this issue). Problematically many disabled people are currently having benefits reduced or removed, yet two in five are restored after appeals. Of the new fitness-for-work tests, one of the architects, Professor Paul Gregg declared in The Guardian (on the 23th of February 201) them to be "badly malfunctioning...a complete mess" and in need of revision, having caused "a huge amount of anguish" because of their stringency. In relation to people from "minority" ethnic background, it has been stated that they suffer a disproportionate risk of social exclusion (Cabinet Office, 2000). People from minority ethnic background have a higher risk/chance for living in the most deprived areas, below average (and poverty-line) incomes, being unemployed or excluded from school, living in bad and overcrowded housing conditions. The Audit Commission (2011) reckoned that $47 \%$ of the cuts local authorities need to do would come from planning, housing and cultural services, despite them comprising only a sixth of all services, meaning real cuts and price increases. King (2012) foresaw closures and more outsourcing. Perry (2011) pointed out that services for migrants have already been cut heavily by the Coalition.

\section{Social Exclusion in Sport: Poverty, Leisure Time Spending and Sport}

Poverty limits and affects leisure spending, evidencing the particularly heavy effects on lone parents and pensioners, as shown in Table 2. While most research has focused on people below the $60 \%$ of median European threshold, Barry (2002) reminded readers that there was an upper threshold. Above this threshold affluent people detach themselves from the rest of society (see also Dorling, 2014). For instance, by buying expensive exclusive memberships to ensure personal service, no crowding and privacy- in 5-star hotels and private resorts, spas, health clubs golf, sailing and rackets clubs as so on.

YouGov (2012) showed life transitions remained the largest reason for dropping out from sports (Sport England, 2013, p. 13), most of which are not amenable to sports policy. The interest in playing varied much less by socio-economic group than actual participation, leading Sport England (2013, p. 23) to conclude "as a result, this is a key driver for many local authorities". Maybe the old lessons of taking sport to the people 
and their doorsteps or communities, tapped by schemes like Action Sport in the 1980s, and Street Games in the UK currently, is worthy of further attention. And perhaps more importantly, worthy of more structural investments. Disadvantaged areas tend to have weak sporting infrastructure and lower sport participation rates. Poor young people are less likely to be club members, compete, and be coached (see Figure 1). Additionally, young people from low-income families volunteered a quarter less in sport clubs than the English average and at barely half the rate of those in prosperity. The Big Society agenda stresses voluntarism as a key component of associational life, but also as substitute for services that are government funded (e.g., social work, caring for the sick) (Ockenden, Hill, \& Stuart, 2012). Data illustrates that volunteers in general are predominantly "white males", showing that sport volunteering is both biased in relation to gender and ethnic-background. In relation to this, Figure 2 shows the Volunteering Equity Index, which Street Games adapted from Sport England's equity index using Active People 2 data.

Table 2. Family expenditure on recreation 2011.

\begin{tabular}{|c|c|c|c|c|}
\hline Type of household/f per week & $\begin{array}{l}\text { Single adult } \\
\text { working age }\end{array}$ & Pensioner couple & $\begin{array}{l}\text { Couple with } 2 \\
\text { children }\end{array}$ & $\begin{array}{l}\text { Lone parent, one } \\
\text { baby } 0-1\end{array}$ \\
\hline Total (excl. housing, childcare) & 241 & 303 & 706 & 767 \\
\hline Social \& cultural spending (\%) & 44 & 49 & 109 & 56 \\
\hline MIS excluding rent/childcare $f$ & 201 & 241. & 471 & 284 \\
\hline $\begin{array}{l}\text { Disposable income as } \% \text { of MIS on } \\
\text { Minimum wage* }\end{array}$ & 72 & NA & 84 & 87 \\
\hline MIS as \% of median income & 82 & 58 & 82 & 85 \\
\hline $\begin{array}{l}\text { Lacking Minimum Income Stand- } \\
\text { ard, million (\% of group) }\end{array}$ & $1.35(34)$ & $0.8(8)$ & $1.84(23)$ & $0.83(57)$ \\
\hline
\end{tabular}

Note: * after council tax, rent \& any childcare costs. Sources: Hirsch (2011), and Padley and Hirsch (2013).

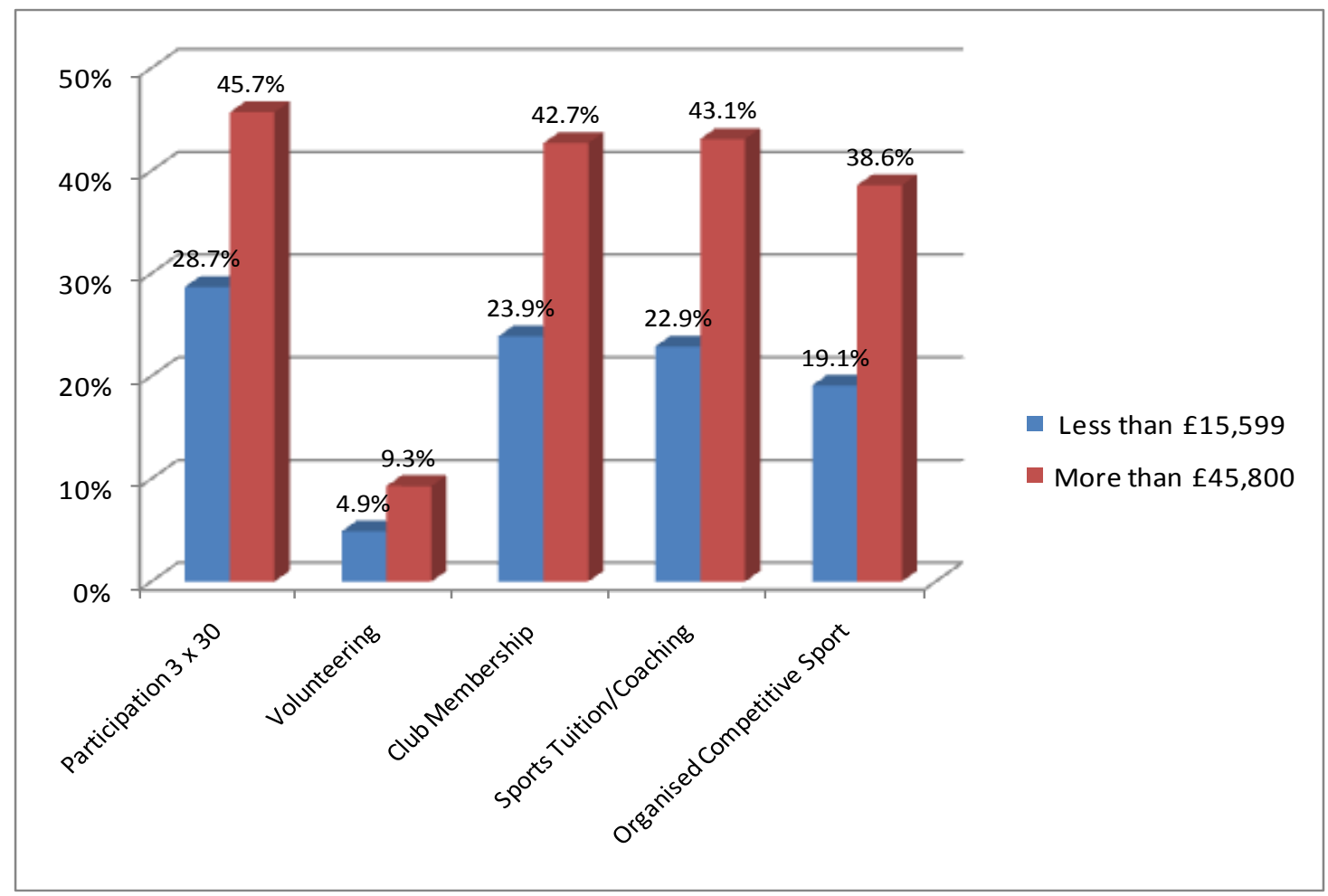

Figure 1. Features of sports participation by 16-25s by income, 2008-2009 (source: Sport England, 2009). 


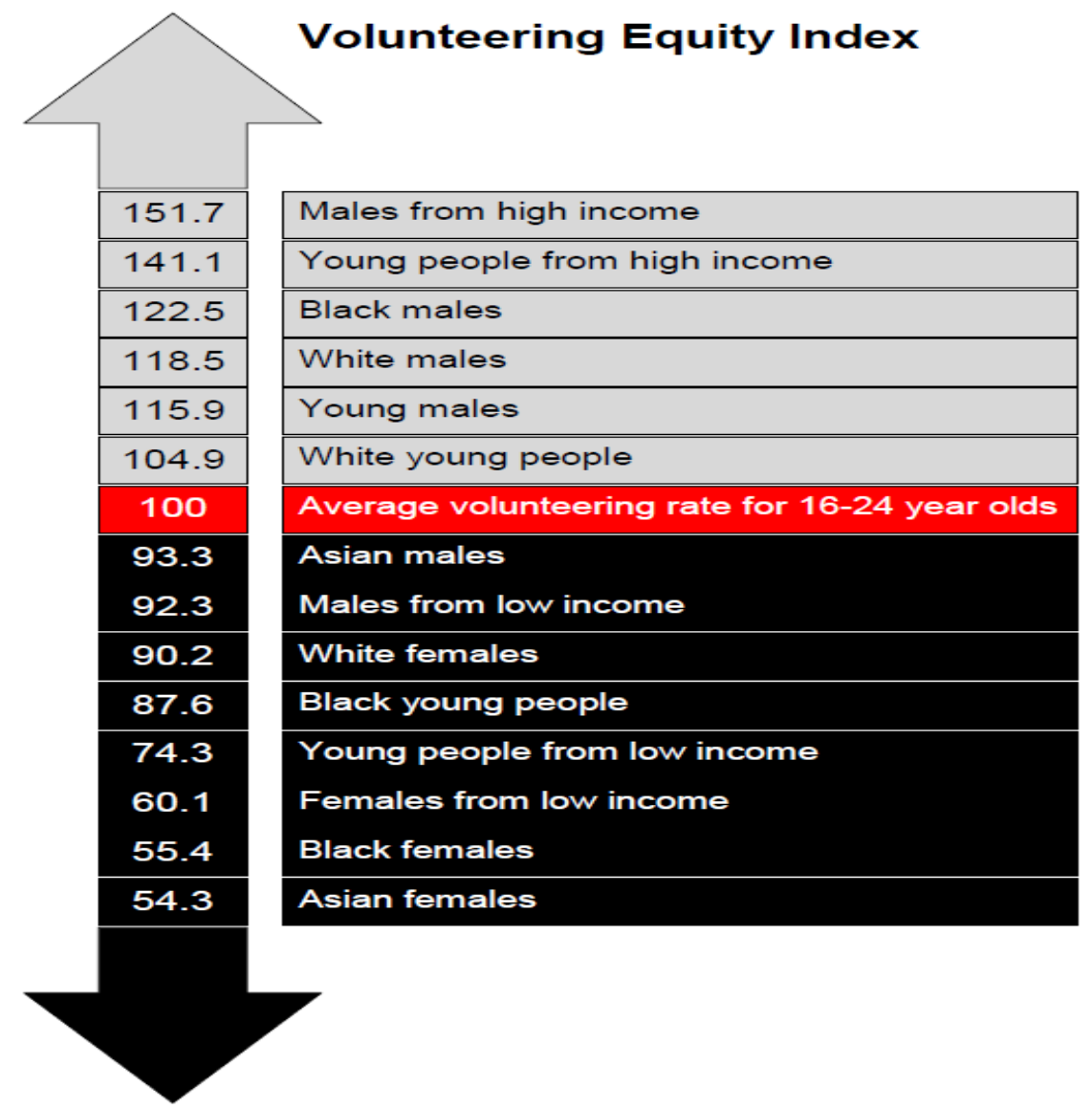

Figure 2. Volunteering Equity Index: Regular volunteering by different groups (sources: Sport England (2009) and Street Games (2009)).

Taking into account that people from a non-western ethnic background and women in general are more likely to be confronted with poverty/social exclusion, and less likely to be volunteering and participating in sports, the perspectives of the austerity measures on such (and other) groups in society, in terms of sport participation, are simply bleak. Such empirical realities have formed the basis of policies targeted at specific groups in society in poverty and social exclusion. To not only include them in sports, but also to combat the negative outcomes of poverty and social exclusionboth on an individual and community level-through sports-based interventions. The latter one is the focus of the next section.

\section{Social Inclusion through Sport: Sports-Based Interventions}

Collins and Kay concluded that successful interventions addressing social exclusion need time and resources to deal with the major structural issues underlying exclusionary processes and actions, in five different ways (Collins \& Kay, 2014, pp. 212-223). Firstly, many sport projects - where resources are modest - run programs for only three years. Which is an understandable lifespan for politicians seeking re-election but only just long enough for many programs to be established, let alone show their outcomes. Collins and Kay (2014) call for policymakers to better resource projects and lengthen the policy span to 7 or 10 years. There is also a tendency to start too many new things to demonstrate political virility, confusing recipients and partners about priorities. There are however exception. For example in England, Sport England's recent initiative (Sport England, n.d.) to establish a satellite sports club in every secondary school and college linked to a community "hub club" has a 2012-2017 timespan and a $f 48 \mathrm{~m}$ budget with an enabling officer in each of the 48 County Sport Partnerships. Unfortunately, such exceptions are not a prelude for an overall policy change, as Kelly (2012) and others (e.g., King, 2012; Levitas, 2012) indicated that in the UK significant funding cuts have led local authorities to suspend many of their own youth (leisure) services and cut grants to other providers, and additionally funding has become more narrowly focused on the early years. Secondly, Coalter (2001, 2007, pp. 19-23, 2011) has criticized sport-based interventions for using a-theoretical monitoring and evaluation approaches (if any monitoring and evaluation are integrated at all). Furthermore, there remains a lack of research projects using control groups, measuring longitudinal effects and understanding if, and if so, how 
programs resonate with different participants, and why? As Coalter (2007) argued there is a clear need for seeking clear logic models and theories of change in relation to sport-based or sport-plus programs in relation to the outcomes such programs wish to attain. Thirdly, in urban areas exclusion and targeted groups are often concentrated, but in rural areas particularly they are dispersed making policies difficult and expensive to target. In any case the areas of concentration may still contain a minority of targeted people. This raises the need for a mixture of people and area-based policies. However it needs to be noted that several authors have raised some pertinent questions in relation to interventions targeted at "disadvantaged or at-risk neighbourhoods and youth"; It is argued that such interventions and policy discourse perpetuate a negative representation of young people and their neighbourhoods and further instigate processes of territorial stigmatization (e.g., Wacquant, 2008), further legitimating interventionist policies (Kelly, 2012). Fourthly, there is a need for sustainable programs, which is easier when funders are tied together in partnerships, and local people are involved at all stages from diagnosis to delivery (Lindsey, 2008). Fifthly and finally, sport has neither the political "clout" nor the policy salience to make major changes on its own, needing the support of political economic and organisational partners (Pierre \& Peters, 2001). Sports clubs are the obvious primary partners but schools, youth and community groups, health and welfare bodies, churches and faiths, trades unions are relevant partners in terms over delivering socially inclusive sport activities. Theeboom, Haudenhuyse and De Knop (2010) have, for example, argued that, in Belgium, the traditional sport sector has never played any significant role in the provision of sport opportunities for underprivileged young people. Instead other providers (e.g. the sectors of young people, education, integration, social affairs, and crime prevention) have gradually become involved in the organisation of specific community sport initiatives (Theeboom et al., 2010). This is perhaps surprising, as most of these "new" providers are traditionally not linked to sports provision. On the other hand this is not so surprising, considering the fact that many of such organisations have historically integrated sport activities in their services and programs, long before there were policy-led sports-based programs for socially excluded groups.

In the next section we will briefly discuss the Positive Futures program. In discussing this case we will, as already mentioned in the introduction, focus on the "inclusion through sport" aspects of the program. Social inclusion in sport describes processes that occur in a sporting context (e.g., equal participation, improved sport skills), whereas social inclusion through sport refers to opportunities that can arise from participating in sport for the involvement within other contexts (e.g., personal/social development; changed behaviour; community regeneration/social capital). It can be noted that a combination is also possible, and often implied. In the sense that offering socially excluded groups accessible sporting opportunities will automatically contribute to wider effects "beyond sport".

\section{Case Study Positive Futures}

Positive Futures was established in 2000 countrywide by the Home Office Drugs Directorate, in partnership with Sport England and the Football Foundation and numerous locals, amongst the most important Youth Offending Teams and Youth Improvement Programs. It was intended to promote sport and physical activity, reduce drug abuse, and modify lifestyles. It was aimed specifically at the most vulnerable and at-risk youth (aged 10-19), in one-fifth of the most deprived areas in England. Crime Concern defines Positive Futures as a "national sport and activity based social inclusion program" (Crime Concern, 2006, p. 6). Though as the program wound on, a wider range of youth were referred from schools, or self-referred. It was monitored by consultants MORI (UK based research company active in multiple research domains), and from 2004 evaluated by Substance (UK-based social research company working in the youth, sport, community and personal development sectors). In 2003 by the end of Phase 1 there were 63 projects. Seventeen of them were in high crime areas. With a combined annual budget of $£ 3.9 \mathrm{~m}, 26,000$ youth were reached, which means an average of 420 per scheme. More than nine out of ten were under 17 and almost one in five from black and minority ethnic background (a term commonly used in the UK to describe people of non-white descent). Phase 2 (spanning from 2003-2006) comprised 56 projects financed by $f 15 \mathrm{~m}$ from the Home Office Drugs Directorate and Football Foundation. Four in five of attending youngsters took part in sport, notably football and basketball, one in eleven in educational activities (notably arts and antidrug advice sessions), and one in twelve in recreations (notably outdoor pursuits and trips). In Cul de sacs and Gateways (Home Office, 2002, p. 4) Positive Futures was described as: "a relationship strategy, based on the principle that engagement through sport and the building of mutual respect and trust can provide cultural 'gateways' to alternative lifestyles." The crucial mentor/leader was a community sports coach. A particular case was made for the ability of football to build relationships through team working. This report aimed to secure more funding, to receive better support from regional agencies, to focus on 17-19s, since most young people hitherto contacted had been aged 10 to 16 , to develop a training element, and to implement better monitoring and evaluation. Sport England's evaluation of the 24 projects it co-funded (Chapman, Craig, \& Whaley, 2002), showed that increases in sport participation, demonstrating the potential importance of sport as a "hook" for youth (see also Nichols, 
2007). Furthermore, in relation to inclusion in sport the evaluation revealed however that girls comprised only a quarter of attenders.

In 2008 the Home Office decided to cease managing Positive Futures. The program was tendered and 91 projects were handed over to charitable voluntary agency Crime Concern, renamed Catch 22 and provided with funding till 2011. Taking it on (Home Office, Substance, \& Catch 22,2008 ) recorded 60,000 youth involved, $22 \%$ female, now $54 \%$ from black minority ethnic groups, and two-thirds self-referred. Football still occupied a third of the provided sessions, but more were multi-sport, and fitness and dance. It recorded specific acts of protection by Positive Futures against 20 risk factors for disadvantaged communities identified by the Youth Justice Board (UK). A decade of support is to be applauded, but as with so many local programs, politicians and senior civil servants who are always looking for new messages and projects might see it as "done that, demonstrated that". While this substantial effort and millions of pounds confirmed most strongly all the lessons drawn out by Nichols (2007) and McCormack (2000), it added some modest further understanding. Now that Positive Futures is rolled into a much wider portfolio of youth support programs for 96,000 youth in a budget of $f 53 \mathrm{~m}$ (Catch 22, 2013), it is now longer identifiable on its own. In 2012-2013 it was involved with new local environmental improvement projects. In 2012 the project installed a national Youth Advisory Board to give young people a voice within the program.

Initially Positive Futures was aimed at "young people aged 10-19 with a focus on engaging those young people who are marginalized within the community" (Crime Concern, 2006, p. 8). Local Positive Futures projects tended to combine "crime reduction" and "social inclusion" objectives. However, Crabbe (2006a) noted a shift towards a crime reduction/prevention emphasis between 2001 and 2006. Resonating with the overall political ideology-with a punitive "war-on-crime" discourse-of the "Big Society". As such, Positive Futures has been more recently described as Britain's largest national youth crime prevention program. More recently, the discourse of the program seemed to have completely shifted towards an early interventions approach for potential drug addicts and juvenile delinquents. For example, the website states that: "Positive Futures is a prevention and diversionary program. Funded by the Home Office, the program targets and supports 10-19 year olds who are at risk of becoming drawn into substance misuse and crime". As indicated, Positive Futures uses a bottom-up locally embedded philosophy, through which local partnerships can envisage their own project. Although working to national strategic aims, Positive Futures projects are locally managed and delivered. They are also highly diverse (Kelly, 2012). Because there is such a diversity of different Positive Futures projects, Kelly (2012) argued that it is questionable whether it makes sense to speak of Positive Futures as a "program" rather than a collection of projects adopting quite different models of provision. This, amongst others presents challenges for researchers interested in establishing the most effective features of the program in relation to combatting social exclusion through sport-based activities (e.g., Crabbe, 2006b).

\section{Inner-Workings of Positive Futures}

Tim Crabbe and his research team did extensive evaluation research and several evaluation reports between 2005 and 2008 on Positive Futures. For example, Crabbe (2005) assessed organisational case studies of different Positive Futures projects, and they argued that Positive Futures should not be driven by referral routes, but use "flexible, pragmatic outreach approaches". Crabbe (2006a) found no ready-made model for partnerships, but argued that voluntary sector forms were often more flexible and appropriate than publicly-imposed ones. In terms of impact they concluded that: "Projects working with fewer participants are more likely to have a significant impact on a higher proportion of those they work with than projects working with large numbers" (Crabbe, 2006b, p. 3). The authors contributed this to a function of the quality of mentoring context with fewer participants could achieve. A striking conclusion was that Positive Futures could also provide physically and emotionally safe places in "danger zones of racialized and territorial conflict" (2006, p. 4). Crabbe (2006b) further opined that the value of sport could only be realised within a social and personal developmental approach. Frontline grassroots youth work experience was necessary to handle the contrasting nature of both diversionary and developmental work. Laura Kelly conducted field research (Kelly, 2011, 2012) within three Positive Futures projects and a pilot site in England. All the projects studies ran predominantly sports-based activity sessions in areas of deprivation, especially estates where most residents are housed by the local authorities. The field research revealed that different key partner agencies were involved in providing the program locally, including: sports providers; local youth justice services; social services departments; education providers; and substance misuse services. Kelly (2012) concluded that partnerships with other practitioners meant resources could be shared, referral pathways managed, and young people better supported. In addition, building links with community members was felt by the program providers to help projects recruit local volunteers and mediate tensions between adults and young people living in the same neighbourhoods. Interview data further indicate young people with learning or behavioural difficulties were known to take part in activities. Because of the range and appeal of the provided sport activities, Kelly argued that that young women could 
be marginalized, since projects usually focused on young people with visible "street lives" (Kelly, 2011). These findings resonate with the evaluative research of Chapman et al. (2002) on Positive Futures.

In relation to social inclusion in sport, Kelly's research indicated that Positive Futures workers acted as referral agents to sports clubs and specialist youth services. The Positive Futures projects Kelly included both the large, open-access community sports activities (where were participant-practitioner ratios were often high and were often staffed by coaches employed on a sessional basis and intensive referral-based provision), but also more specialized services. Kelly (2012) argued that: "while relationship building was highlighted by both interviewed young people and practitioners within many aspects of Positive Futures work, varying levels of support were available in different parts of the projects data collected from staff and young people at those sites also contain references to relationships, staff working on a one-to-one basis with young people were able to offer much more intensive support, for example by telephone or after standard working hours". Throughout the several evaluation reports that Crabbe and colleagues produced, strategies enabling coaches and youth workers to build relationships with young people were often identified as key mechanisms. These one-to-one and targeted services were reported to be more likely to work with young people experiencing multiple difficulties. Such findings correspond with other research on Positive Futures project (Crabbe, 2006b; Nichols, 2007). For example, Nichols (2007) concluded that the researched Positive Futures project had an impact through the process of longterm personal development, and that the quality of the relationship between youths and sports leaders was crucial. The quality was said to be highly dependable of the skills and enthusiasm of the staff. However, this requires long-term funding to attract and retain the, as Nichols (2007, p. 118) called: the "right calibre of staff and give them time to build up relationships with young people". Problematically, the changing arrangements of funding both on a national and local level-which is typical for programs such as Positive Futures-makes it difficult to create the sufficient and most optimal conditions for this, as program providers may spend more time looking and applying for funding rather than delivering, monitoring and evaluating services in order to attain the highest quality in terms of participant-sport leader relationships.

The field research conducted by, for example, Kelly (2012) showed some evidence that projects changed young people in terms of improved pathways to education and employment opportunities, however: "All studied sites were able to demonstrate beneficial impact in the form of personal testimonies, projectproduced case studies and partner reports. As previous work from this project has explored, however, out- come data collated by the studied projects suggest that (known) successful outcomes were restricted to a relatively small number" (Kelly, 2011). In terms of social inclusion through sport, Kelly (2012) argued that Positive Futures workers act as "advocates" and "mediators" with the potential to influence policy and practice. Kelly recommends that research into the using sport as a social inclusionary intervention, should focus and generate more understanding regarding the extent to which youth workers and sport practitioners facilitate influence on policies and practices affecting participants.

\section{Critical Perspectives}

From a more critical perspective, Positive Futures could be viewed as, what Ramon Spaaij (2013) referred to as, interventions that are part of a neoliberal policy repertoire aimed at generating social order in disadvantaged neighbourhoods. Disadvantage that is instigated by a government retrenching in (social) services to the public and austerity measures. The impact of individualized intervention programs, such a Positive Futures, is according to Kelly (2012) limited by their sheer inability to alter substantially the adverse socio-cultural contexts in which social exclusion occurs. Or as Coalter argued (2013), it is perhaps more effective and realistic to change the odds, instead of expecting time and again disadvantaged groups to beat insurmountable odds through limited-focused sport-based interventions. Related to this, Nichols (2007) argued that Positive Futures programs were not designed to deal with multiple problems young people face, such as housing and employment, but notwithstanding this sport leaders had to deal with such daily realities in order for participants to be able to stay on the program. More problematically, since Positive Futures explicitly aims at a focusing on engaging those young people who are marginalized within the community" (Crime Concern, 2006, p. 8), Kelly (2012) suggested that in order to secure funding, managers and practitioners will feel pressurized to emphasize the riskiness or level of disadvantage of their participants. This has, according to Kelly (2012) at least two problematic (unintended) outcomes. Firstly, as already indicated above, the discourse of interventions targeting the most at-risk or vulnerable young people perpetuates a negative representation and territorial stigmatization of specific groups in society and the neighbourhoods they live in. Secondly, new models of funding and a payment-byresults accountability risk introducing new incentives, as Kelly $(2012$, p. 114) put it, that "focus on less challenging (potential) participants and prioritize short-term interventions over long-term relationship building". What is more, research has illustrated how youth programs pursuing fixed externally defined outcomes potentially have the perverse effect of excluding those who differ most from a desired developmental trajectory or pro- 
gram endpoint (Coussée, Roets, \& De Bie, 2009; Tiffany, 2011). This is especially relevant if such a trajectory or endpoint is conceptualized based on mainstream conventions and practices regarding education, employment or positive youth development, conventions and practices that are perpetuated by the same institutions (for example, schools and career services) that make young people vulnerable in the first place (Haudenhuyse, Theeboom, \& Nols, 2013). In this context, Tiffany and Pring (2008) have argued that the most marginalized young people are less likely to participate in highly structured and pre-described leisure activities. This paradoxical consequence of strategies that concentrate on implying individual solutions to social exclusion has been coined by Tiffany (2011) as a "Pistachio Effect", in which the harder nuts to crack are, at best, left until later, or at worst, simply disregarded.

This stark scepticism and criticism is by no means an argument to stop funding or implementing programs like Positive Futures, as sport can bring joy and achievement for many people who have not had much of either in other spheres of their lives so far. According to Collins and Kay (2014) if such programs can be a policy partner and a tool (albeit a small one) for combatting social exclusion, to be effective, sport-based inclusionary programs need to be much more people-focused; longer term, better led, and designed with and not just for the people and organization intended to be beneficiaries. Additionally, as Haudenhuyse, Theeboom and Coalter (2012, p. 450) indicated sport-based practices could be viewed as contexts that, through working with youth, provide us the understanding how the structures and arrangements of society exclude young people in the first place. Such an understanding is according to Haudenhuyse et al. (2012) critically important if we wish to meaningfully intervene in the lives of young people living in poverty and being confronted with social exclusion. However, under an austerity regime, the individualization and moralization of broad societal problems such as poverty, the-often unintended-negative representations of youth facing social exclusion and living in deprived areas, the exclusion of harder-to-include youth (as an organizational survival strategy fuelled by a payment-by-results logic) and the underfinancing of sportbased programs, are likely only to worsen under what has been described as a "neo-liberal shock doctrine" (see Levitas, 2012). According to Ekholm (2013), research on sport as a means for wider social "inclusionary" outcomes should be "approached from a social constructionist perspective, focusing on the construction of meaning, knowledge and the significance of sport in terms of ideology and welfare" (p. 115). Ekholm (2013, p. 115) argues that such an approach could further problematize and critically expose the underlying assumptions, distinctions, ideologies and research positions that constitute the conceptions surrounding sport as a means for social inclusion.

\section{Concluding Thoughts}

When writing this paper, Eurostat (2015) published a report showing the progressing of the EU 2020 targets the European Union set out for itself in 2010. The key objectives of the EU 2020 strategy are expressed in the form of five targets in the areas of employment, research \& development (R\&D), climate change \& energy, education and poverty reduction, to be reached by 2020. In relation to employment rates and people at risk of poverty and social exclusion, the Eurostat report shows a distancing in these two domains from the targets the EU set out. The Europe 2020 strategy has set the target of lifting at least 20 million people out of the risk of poverty and social exclusion by 2020 . However, the Eurostat progression report indicates that the EU is in terms of poverty and social exclusion drifting away from the targets it set out for itself. In other words, between 2008 and 2013 more people have been driven into poverty and social exclusion. Although The United Kingdom has not adopted specific national Europe 2020 targets, Eurostat (2015) shows that after the deterioration in employment rates during the economic crisis (2008 to 2011), the indicator increased again to $74.9 \%$ in 2013 , exceeding the EU average of $68.4 \%$. Furthermore, according to Eurostat (2015) the development in the area of poverty has been equally unfavourable, with the number of people at risk of poverty or social exclusion peaking at in 2013. Amongst all the European countries (incl. eastern European countries such as Bulgaria and Romania) only Italy scores worse than the UK. Recently, Jenkins (2015) estimated that UK and EU-15 poverty rates are expected to increase by around two percentage points in the following four years.

Our opening sentence began with stating that 2010 was the European Year of Social Inclusion, through which the EU confirmed the role of sport as "a driver of active social inclusion" (Council of the European Union, 2010), with particular reference to accessibility, disadvantage and gender. But in Britain, sport's puny policy leverage-what Coalter (2013, p. 18) called "epiphenomenal, a secondary set of social practices dependent upon and reflecting more fundamental structures" - is powerless against the structural forces listed above. And one must expect it to suffer inequity and exclusion to at least as great as other sectors of society. Levitas (2012) argued that since the austerity measures of the Coalition government, all local authority services are at risk of reduction or complete disappearance, including youth clubs and other leisure provisions. Sport services have always been "under threat", but King (2013) argues that the reductions to local government finance and the political orientation away from state provision, will lead to sport services facing their most serious threat to date. In contrast to the previous Labour government that prioritized sport as an instrument to tackle social exclusion and widening participation, the Coa- 
lition government has discontinued area-based grants that supported interventions to promote social inclusion in and through sport (King, 2012, p. 352). According to King (2012), the Coalition government reduced local governance finance via a $28 \%$ cut to the department for Communities and Local Government budget over four years. Such cuts have led to the curtailment of sport services as an area of discretionary spend. This rolling back in Sport-for-All and Sport-for-Good policies (and programs), is in stark contrast with the Coalition governments support for the 2012 Olympic games, of which the impact on the wider sport participation of people living in England and the assumed urban regenerative outcomes are debatable to non-existent (Collins \& Kay, 2014).

While the economy is better in Britain than in Greece, Portugal or Spain and many other countries, this litany suggests that social polarization is again increasing (Dorling, 2010, 2014).The social divides in health, lifespan and quality of life so graphically illustrated by Marmot (2010, 2011)-including sport and leisureseem unlikely to reduce for a long time. Looking globally, Piketty (2013) took a more radical view that capitalism seeks to gather wealth into ever-fewer, powerful hands, outstripping the attempts of super-managers in financial services, oil trading, biotechnology, electronics, etc., to pay themselves ever-larger salaries and bonuses, and without thought for inequity. Hills, Sefton and Stewart (2009) spoke of a "tide turned but mountains left to climb". But the tide is on the flood again, increasingly raising moral issues, for example, that inequity is unjust (Rawls, 1971) as well as economic ones, for example, that poverty is a waste and inefficient (Wilkinson \& Pickett, 2009). Against such unsurmountable odds, the question can be raised what sport, as a puny policy leverage (Houlihan \& Lindsey, 2013) can possible mean against wider powerful social structures generating inequity and exclusion. And this on the one hand in terms of inclusion in sport and addressing processes of social exclusion that hinders people from doing sports, which are mainly beyond the scope of sport policy and seem to be further worsened by the austerity measures. But on the other hand, also in terms of inclusion through sport and addressing the implications of austerity measures on the closure of sport-based social inclusion schemes (such as Positive Futures), and their increasing inadequacy in the face of social exclusion.

It is important to note that the research conducted for the case study of Positive Futures is from 2012 (although field data were gathered earlier). The abovedescribed trends in poverty in England since the financial crash need to be situated from 2008 and onward. It is likely that the impact of the austerity measures did not influence projects such as Positive Futures during the time field research was conducted in the reported studies. The impact of any policy measure is likely to manifest itself only after some time. For example, according to
Sabatier (2007) the impact of most policy measures can take up to 10 years. Although we might argue that some policy measures in terms of, for example, welfare benefits or social support policy measures for people living in poverty (e.g. social housing) can have a more direct short-term effect on the lives of people in poverty. More research would be needed to see how this and other case studies can be positioned in relation to more current poverty trends and the effects of policy measures taken in 2010. These points notwithstanding, the case study described here focuses on the possible impact and frictions of "austerity" policies on poverty, social exclusion and sport. And in particular the implications this could have on interventions targeted to combat social exclusion or promote social inclusion and the broader contexts in which sports-based interventions are run.

\section{Acknowledgments}

The first author is grateful to Ceris Anderson for Figures 1 and 2 . The second author would like to thank the anonymous reviewers for their constructive and insightful comments on earlier drafts of the paper.

\section{Conflict of Interests}

The authors declare no conflict of interests.

\section{References}

Amara et al. (n.d). The roles of sport and education in the social inclusion of asylum seekers and refugees: An evaluation of policy and practice in the UK. Research Report. Retrieved from http://assets.sport anddev.org/downloads/the_roles_of_sport_and_e ducation_in_the_social_inclusion_of_asylum_ seekers_and_refuge.pdf

Audit Commission. (2011). Tough times: Councils' responses to a challenging financial climate. London: AC.

Barry, B. (2002). Social exclusion, social isolation, and the distribution of income. In J. Hills, J. Le Grand, \& D. Piachaud (Eds.), Understanding social exclusion (pp. 13-22). Oxford: Oxford University Press.

Cabinet Office (2000). Minority ethnic issues in social exclusion and neighbourhood renewal. London: Cabinet Office.

Catch 22. (2013). Impact report 2012-2013 London: Catch 22.

Chapman, J., Craig, S., \& Whalley, C. (2002). Positive Futures: A review of impact and good practice, summary. London: Sport England.

Clarke, J., \& Newman, J. (2012). The alchemy of austerity. Critical Social Policy, 32(3), 299-319.

Coalter, F. (2001). Realising the potential of cultural services: the case for sport. London: Local Government Association. 
Coalter, F. (2007). A wider role for Sport: Who's keeping the score? London: Routledge.

Coalter, F. (2011). Sport conflict and youth development. Stirling: Stirling University.

Coalter, F. (2013). Game plan and the spirit level: The class ceiling and the limits of sports policy? International Journal of Sport Policy and Politics, 5(1), 3-19.

Collins, M. and Kay, T. (2003). Sport and social exclusion. London: Routledge.

Collins, M. and Kay, T. (2014). Sport and social exclusion. London: Routledge.

Cooper, N., \& Dumpleton, S. (2013). Walking the breadline: the scandal of food poverty in the $21^{\text {st }}$ Century Britain. Manchester: Church Action on Poverty/Oxfam.

Council of the European Union. (2010). Conclusions of 18 November 2010 on the role of sport as a source and driver for active social inclusion (Official Journal 3.12.2010 C326/5-7). Brussels: Council of the European Union.

Coussée, F., Roets, G. \& De Bie, M. (2009). Empowering the powerful: Challenging hidden processes of marginalization in youth work policy and practice in Belgium. Critical Social Policy, 29(3), 421-442.

Crabbe, T. (2005). "Getting to know you": Engagement and relationship building: Case study report. Sheffield: Sheffield Hallam University.

Crabbe, T. (2006a). Going the distance. Sheffield Hallam University.

Crabbe, T. (2006b). Knowing the score: Positive Futures final case study report. London: Home Office.

Crime Concern. (2006). Splash-A guide for scheme organisers. Swindon: Crime Concern.

Crul, M., Schneider, J., \& Lelie, F. (2013). Superdiversiteit, een nieuwe visie op integratie. Amsterdam: VU University Press.

Dierckx, D., \& Ghys, T. (2013). Solidariteit en herverdeling in structurele armoedebestrijding [Solidarity and redistribution in structural poverty reduction]. In D. Dierckx, S. Oosterlynck, J. Coene, \& A. Van Haarlem (Eds.), Armoede en sociale uitsluiting [Poverty and social exclusion]. Leuven: Acco.

Dorling, D., Rigby, J., Wheeler, B., Ballas, D., Thomas, B., Fahmy, E., Gordon, D., \& Lupton, R. (2007). Poverty, wealth and place in Britain, 1968-2005. Bristol: Policy Press.

Dorling, D. (2010). Injustice: Why inequality persists. Bristol: Policy Press.

Dorling, D. (2014). Inequality and the 1\%. London: Verso Books

Ekholm, D. (2013). Research on sport as a means of crime prevention in a Swedish welfare context: A literature review. Scandinavian Sport Studies Forum, 4, 91-120.

Eurostat (2015). Smarter, greener, more inclusive? Indicators to support the Europe 2020 strategy. Eurostat statistical books. Luxembourg: Publications Of- fice of the European Union.

Ghys, T. (2014). Naar een structurele theorie van armoede. In S. Oosterlynck, G. Verschraegen, D. Dierckx, F. Vandermoere, \& C. de Olde, Over gevestigden en buitenstaanders [On the established and outsiders] (pp. 275-295). Acco: Leuven.

Giddens, A. (2001). Sociology. Cambridge: Polity Press.

Haudenhuyse, R. (2015). Sport, social exclusion and the forgotten art of researching poverty: Book review of sport and social exclusion (2nd ed.). By Mike Collins and Tess Kay. New York: Routledge, 2014, 320 pp.; ISBN: 978-0-415-56880-7. Social Inclusion, 3(3), 153-157.

Haudenhuyse, R., Theeboom, M., \& Coalter, F. (2012). The potential of sports-based social interventions for vulnerable youth: Implications for sport coaches and youth workers. Journal of Youth Studies, 15(4), 437-457.

Haudenhuyse, R., Theeboom, M., \& Nols, Z. (2013). Sports-based interventions for socially vulnerable youth: Towards well-defined interventions with easy-to-follow outcomes. International Review for the Sociology of Sport, 48(4), 471-484.

Hills, J, Sefton, T., \& Stewart, K. (Eds.). (2009). Towards a more equal society? Poverty, inequality and policy since 1997. Bristol: Policy Press.

Hirsch, D. (2011). Minimum Income Standard for the UK 201. York: Joseph Rowntree Foundation.

Home Office. (2002). Positive Futures: Cul de sacs and gateways. London: HO.

Home Office, Substance, \& Catch 22. (2008). Taking it on. London: HO.

Houlihan, B. M. J., \& Lindsey, I. (2013). Sport policy in Britain. London: Routledge.

Jenkins, S. (2015). The income distribution in the UK: $A$ picture of advantage and disadvantage (Paper 186). London: Centre for Analysis of Social Exclusion (CASE).

Kelly, L. (2011). "Social inclusion" through sports-based interventions? Critical Social Policy, 31(1), 126-150.

Kelly, L. (2012). Representing and preventing youth crime and disorder: Intended and unintended consequences of targeted youth programs in England. Youth Justice, 12(2), 101-117.

King, N. (2012). Local authority sport and recreation services in England: What next? Manchester: Association for Public Sector Excellence.

Levitas, R., Pantazis, C., Fahmy, E., Gordon, D., Lloyd, E., \& Patsios, D. (2007). The multi-dimensional analysis of social exclusion (Research Report). London: Department for Communities and Local Government.

Levitas, R. (2012). The just's umbrella: Austerity and the Big Society in Coalition policy and beyond. Critical Social Policy, 32(3), 320-342.

Lindsey, I. (2008). Conceptualising sustainability in sport development. Leisure Studies, 27(3), 279-294.

Marmot, M. (2010). Fair start, healthy lives: Strategic 
review of health inequalities in England post 2010. London: The Marmot Review.

Marmot, M. (2011). Fair society, healthy lives Marmot report 1 year on, presentation to BMA Press conference 10 February 2011.

McCormack, F. (2000). Leisure exclusion? Analysing interventions using active leisure with young people offending or at-risk. Unpublished PhD thesis, Loughborough University.

McKnight, A. (2014). Disabled People's Financial Histories: Uncovering the disability wealth-penalty. Centre for Analysis of Social Exclusion (CASE). Paper 181.

National Children's Bureau. (2013). Greater expectations: Raising aspirations for our children. London: NCB.

Nichols, G. (2007). Sport and crime reduction. London: Routledge.

Ockenden, N., Hill, M., \& Stuart, J. (2012). The Big Society and volunteering: Ambitions and expectations. In A. Ishkanian \& S. Szreter (Eds.), The Big Society debate: A new agenda for social welfare? Cheltenham: Edward Elgar.

Office of National Statistics. (2013). Working and workless households (ONS Statistical Bulletin 28 August). London: ONS.

Padley, M., \& Hirsch, D. (2013). Household Minimum Income Standard 2008-2009 to 2011-2012. York: Joseph Rowntree Foundation.

Perry, J (2011). UK Migration: The leadership role of housing providers. York: Joseph Rowntree Foundation.

Pierre, J., \& Peters, B. (2001). Governance, politics and the state. Basingstoke: MacMillan.

Piketty, T. (2013). Capitalism in the 21st Century. Cambridge: Belknapp/Harvard University Press.

Prince Trust. (2014). Prince's Trust Youth Index 2014. London: Macquarie.

Rawls, J. (1971). A theory of justice .Cambridge: Harvard University Press.

Sabatier, P. (2007). Theories of policy processes. Boulder: Westview press.

Spaaij, R. (2013). Changing people's lives for the better? Social mobility through sport-based intervention programmes: opportunities and constraints. European Journal for Sport and society, 10(1), 53-73.
Sport England. (n.d.). Satellite club guide. London: SE.

Sport England. (2009). Active People Survey 2008-09. London: SE.

Sport England. (2013). How we play: The habits of community sport. London: SE.

Standing, G. (2011). The precariat: The new dangerous class. New York: Bloomsbury Academic.

Street Games. (2008). Strategic Plan 2008-2012. London: SG.

Street Games. (2009). How race, gender and income affect volunteering rates (Briefing paper 6). London: SG.

Theeboom, M., Haudenhuyse, R., \& De Knop, P. (2010). Community sports development for socially deprived groups: a wider role for the commercial sports sector? A look at the Flemish situation. Sport in Society, 9(13), 1395-1413.

Tiffany, G. (2011). Modern day youth work and the pistachio effect. Paper presented at Youth Policy Seminar: Youth Policy the Day After Tomorrow, Antwerp, Belgium, 8-10 June 2011.

Tiffany, G., \& Pring, R. (2008). Detached youth work: Democratic education (Nuffield Review of 14-19 Education and Training, England and Wales, Issue Paper 11). London: Nuffield Foundation.

Van Haarlem, A., \& Raeymaeckers, P. (2013). Multidimensionele armoede in Europa [Multi-dimensional poverty in Europe]. In D. Dierckx, S. Oosterlynck, J. Coene, \& A. Van Haarlem, Armoede en sociale uitsluiting [Poverty and social exclusion]. Leuven: Acco.

Vermeulen, S., Vloeberghs, E., Van Heur, B., Oosterlynck, C., \& Van de Ven, J. (2012). Kan de stad de wereld redden? [Can the city save the World?]. Brussels: VUB Press.

Vertovec, S. (2007). Super-diversity and its complications. Ethnic and Racial Studies, 30 (6), 1024-1054

Wacquant, L. (2008). Urban outcasts: A comparative sociology of advanced marginality. Cambridge: Polity.

Wilkinson, R., \& Pickett, K. (2009). The Spirit level: Why more equal societies nearly always do better. London: Allan Lane/Penguin Press.

Women's Resource Centre. (2013). Women's Equality in the UK: A health check (Plus Appendix 25 Women \& sport (online)). London: WRC.

YouGov. (2012). How to develop a sporting habit for life. London: Sport England.

\section{About the Authors}

\section{Mike Collins}

Mike Collins was a Senior Lecturer in Recreation Management at Loughborough University for over ten years before "retiring" to part-time work in Sports Development and Faith Communities at the University of Gloucestershire. Prior to holding this position he founded and directed the Institute of Sport and Recreation Planning and Management at the same university for five years. He was Head of Research Strategy and Planning at the Sports Council from its founding, and active in the Council of Europe and what is now the Countryside Recreation Network. He then became Professor of Sports Development at the University of Gloucestershire. Mike Collins passed away in the summer of 2014. 


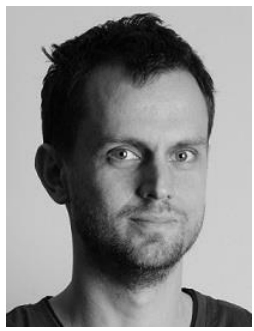

\section{Dr. Reinhard Haudenhuyse}

Reinhard Haudenhuyse has a Master's degree in Physical Education. He holds an additional Master's degree in Conflict and Development (Third World Studies). In 2012, Reinhard received his PhD, entitled "The Potential of Sports for Socially Vulnerable Youth", in Physical Education and Movement Sciences at the Vrije Universiteit Brussel. His work focuses on the impact of sport on an individual, group and societal level, with specific attention to people living in disadvantaged and precarious situations. 